\title{
Ethnoecological appraisal, mineral and phytochemical analysis of five species of Myrtaceae in University Campus, Peshawar, Pakistan
}

\author{
Sikandar Shah ${ }^{1}$, Sheharyar Khan ${ }^{1 *}$, Syed Mukaram Shah ${ }^{2}$, Sumbal \\ Khan $^{1}$, Lubna Khatak ${ }^{1}$ and Gul Rukh ${ }^{1}$ \\ 1. Department of Botany, University of Peshawar-Pakistan \\ 2. Centre of Plant Biodiversity, University of Peshawar-Pakistan \\ *Corresponding author's email: sheharyarbotany@uop.edu.pk \\ Citation \\ Sikandar Shah, Sheharyar Khan, Syed Mukaram Shah, Sumbal Khan, Lubna Khatak and Gul Rukh. \\ Ethnoecological appraisal, mineral and phytochemical analysis of five species of Myrtaceae in University \\ Campus, Peshawar, Pakistan. Pure and Applied Biology. Vol. 10, Issue 1, pp244-252. \\ http://dx.doi.org/10.19045/bspab.2021.100025
}

\begin{tabular}{llll}
\hline \hline Received: 19/06/2020 & Revised: 24/08/2020 & Accepted: 01/09/2020 & Online First: 17/09/2020 \\
\hline \hline
\end{tabular}

\section{Abstract}

The current work was carried out to inspect the ecological features, ethnobotanical importance, elemental and phytochemical integrants of Callistemon lanceolatus, Eucalyptus camaldulensis, Myrtus communis, Psidium guajava and Syzygium cumini of Myrtaceae from district Peshawar. Ethnobotanical profile showed that $(80 \%)$ plants were used in medicines, $(60 \%)$ as fuel and $(40 \%)$ as each lumber, fruits and decorative. Leaf size classification showed that Mesophylls were dominant (40\%) while Microphyll, Nanophyll and Macrophyll were each (20\%). Life form spectrum were dominated by Mesophanerophytes and Megaphanerophytes each (40\%) and Nanophanerophytes $(20 \%)$. (60\%) species were at pre-reproductive while (40\%) in reproductive stage. 13 elements (Carbon (C), Nitrogen (N), Oxygen (O), Magnesium (Mg), Potassium (K), Phosphorus (P), Sulphur $(\mathrm{S})$, Calcium $(\mathrm{Ca})$, Aluminum $(\mathrm{Al})$, Silicon $(\mathrm{Si})$, Iron $(\mathrm{Fe})$, Chlorine $(\mathrm{Cl})$ and Sodium $(\mathrm{Na})$ were analyzed which were quantitatively different from taxa to taxa. Phytochemical constituents like anthraquinones, flavonoid, saponins, terpenoids, tannins, phlobatannins and steroids were screened out in the Ethanolic extract of leaves. The secondry metababolies were unequally dispersed among the five species. The current study is an attempt to assess mineral and phytochemical ingredients of five species of Myrtaceae collected from Peshawar, University campus.

Keywords: Ethnoecology; Ethnobotany; Minerals; Peshawar campus; Phytochemicals

\section{Introduction}

Plants are vital for human beings as they are the spring of energy, wood, powder, medicines and food [1-4]. In developing countries more than $80 \%$ Population depend on medicinal plants for their primary health care [5]. This is because of their limited availability to hospitals, basic health care facilities and high prices. Therapeutic plants and plants based natural medicines are widely used in developing countries in basic health care systems, and much appreciated in developed nations [4]. The investigation of medicinal plants through Quantitative elemental and phytochemical analysis has become significant from last few decades. These techniques are using universally for novel reports, authentication and find out the medicinal importance of the species. The phytochemical screening approach is measured as one of the effective 
techniques in determining biologically active profile of medicinal taxa of therapeutic importance. Elemental screening by EDX is considered as one of the proficient and active technique to highlight the elemental profile of medicinal plants. Myrtle is a recognized for its giant trees, rich in volatile lubricates, tough leaves with greasy external surface and used in various prescriptions [6]. The family has an extensive humid and moderate distribution with more than 3800 taxon and about 138 genera. It comprises various economically important fruits plants and agricultural species [7]. Psidium guajava is an evergreen small tree with leaves hold antiseptic, anti-cough and anti-microbial properties [8]. The vital oil extracted from Eucalyptus was castoff as a medicine for cough, cold and as adenoidal drops [9]. World highest plant Eucalyptus species also belongs to family Myrtaceae. Herbal system of drugs documented the use of Syzygium cumini in liver stimulant, toughen teeth, stomach problems and a very virtuous cream against worm infections of the skull $[6,10]$. Callistemon species are widely used in agriculture, forestry, essential lubricant production, degraded terrestrial retrieval and for decorative drives [11, 12]. Myrtus communis is used as blood cleanser, antihyperglycemic, antimicrobial and for numbing activities [13].
The elemental configuration of the species was find out through Energy Dispersive Xray (EDX) Spectrometer. Secondary metabolites are active constituents present in all plant parts utilized in medications in primary health care. The objective of the present study is to examine ethnobotanical importance, elemental profile and phytochemical compoents of economically important species of Myrtaceae.

\section{Materials and Methods}

Study area and climate

Peshawar is the sixth biggest city of Pakistan situated in the middle of Province Khyber Pakhtunkhwa. Its topographical position is $33^{\circ} 44^{\prime}$ and $34^{\circ} 15^{\prime}$ north latitudes and $71^{\circ} 22^{\prime}$ and $71^{\circ} 42^{\prime}$ east longitudes. It is confined by District Mohmand and Khyber districts on the west, Nowshera on the east, Kohat on the south and District Charsadda on the north (Fig. 1). Edaphology associated with the outcome of soil on active organisms mostly plants. The vegetation cover of Peshawar has a great diversity due to joint deposits of silt, sand and clay soil. Climatically the area has extreme weather condition with very hot summer $\left(40.8^{\circ} \mathrm{C}\right)$ and mild winter $\left(18.35^{\circ} \mathrm{C}\right)$. The extreme rain precipitation occurs in the month of September having $(114 \mathrm{~mm})$ and lowest $(50.0 \mathrm{~mm})$ in June.

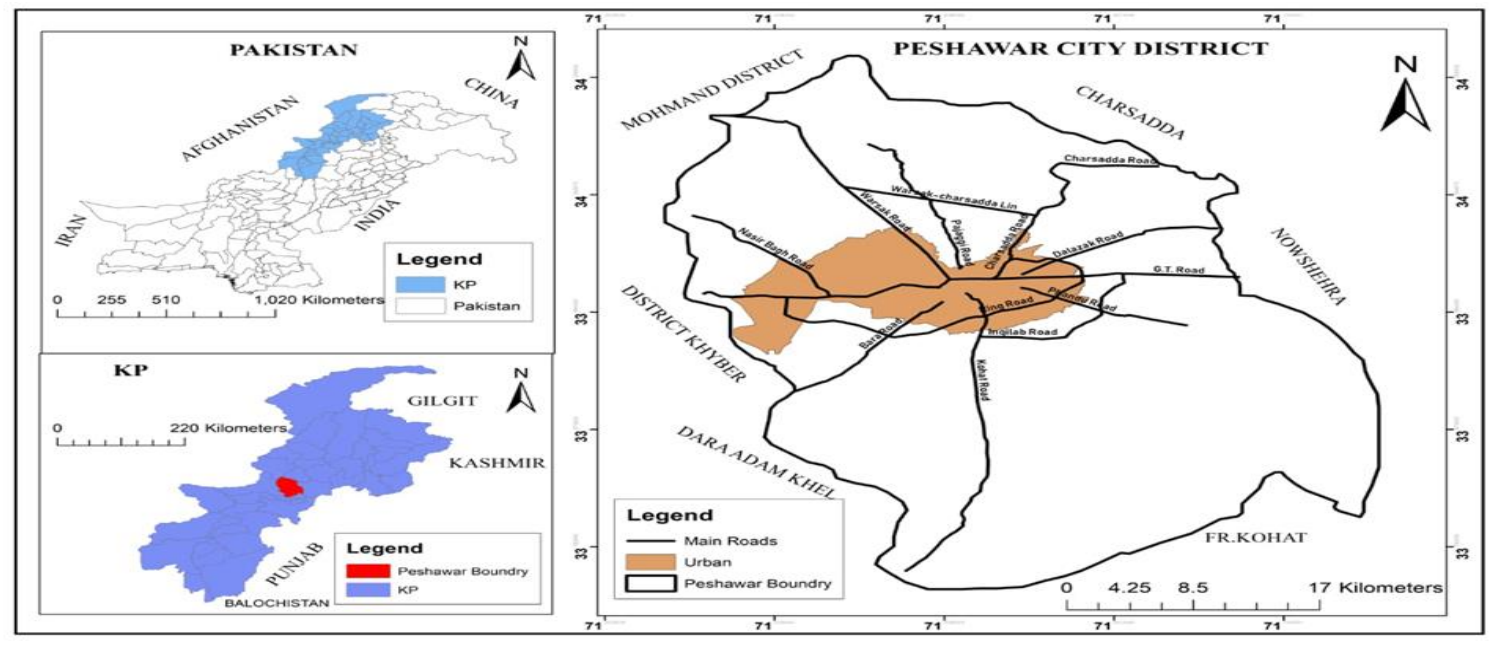

Figure 1. Map of study area: Source; GIS Department, UOP 


\section{Collection of plant leaves}

Fresh leaves of five species of Myrtaceae, Callistemon lanceolatus, Eucalyptus camaldulensis, Myrtus communis, Psidium guajava and Syzygium cumini were collected from Peshawar University campus (Fig. 2). The plant specimens were identified by taxonomists in the herbarium of Department of Botany, University of Peshawar. The leaves were washed, shade dried for fifteen days, crushed into powder through electrical grinder and kept in polythene bags with appropriate labeling.
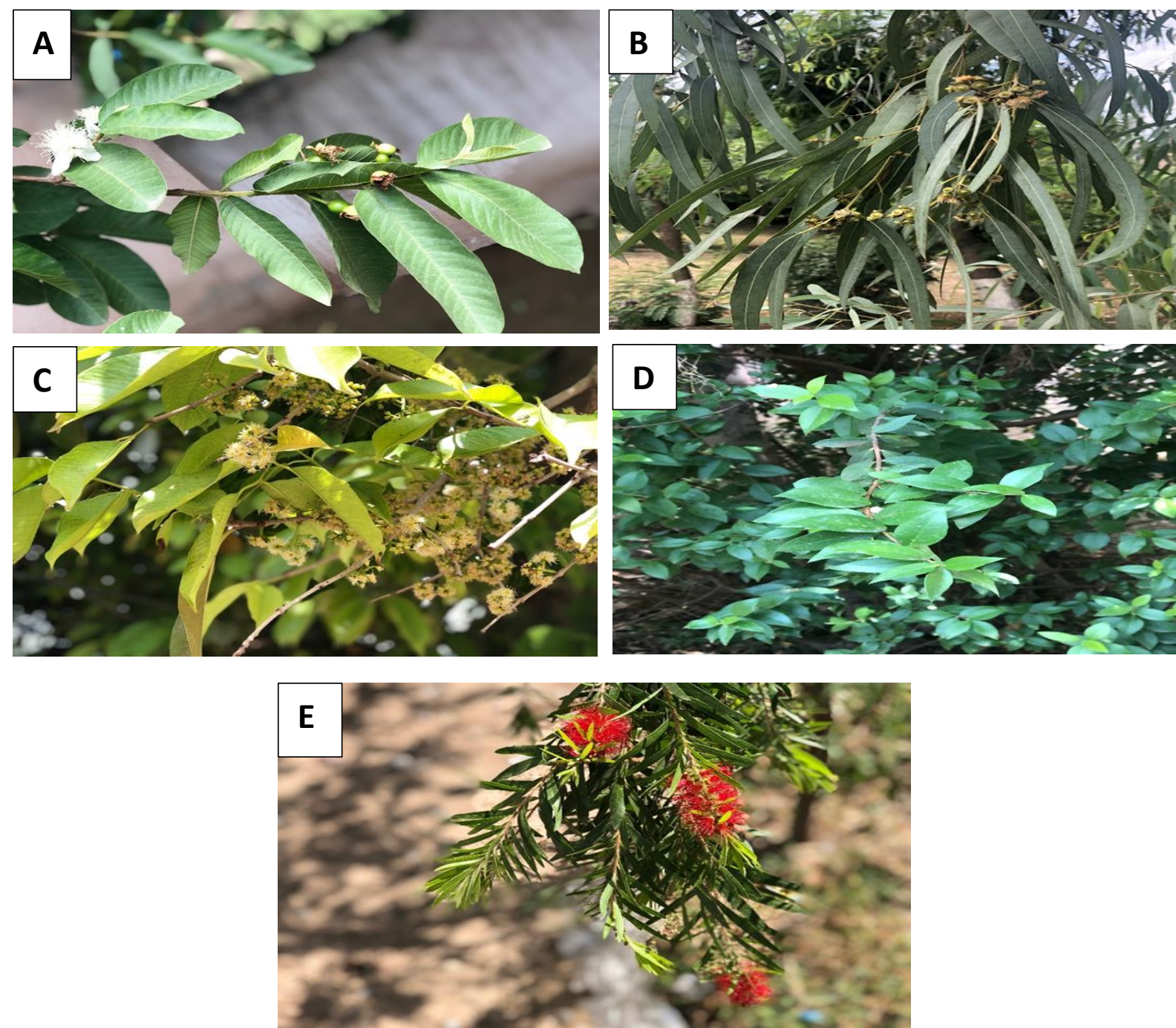

Figure 2. Keys: A. Psidium guajava; B. Eucalyptus camaldulensis; C. Syzygium cumini; D. Myrtus communis; E. Callistemon lanceolatus

\section{Ethnobotanical and ethnomedicinal profile}

Ethnobotanical topographies of plants vary from habitat to habitat. Biological spectra like leaf size, life form, leaf shape and phenology were observed following [1214]. Ethnobotanical studies play an important role in emphasizing significance of plant species in an area. Ethnobotanical and ethnomedicinal uses of the plants were composed through semi structured questionnaire from old aged people and local herbalists. The species were investigated for ethnobotanical uses such as fruit, timber, fuel and medicines.

\section{Phytochemical assesement}

\section{Preparation of extract}

60 grams of each plant powder were added in a conical flask containing $270 \mathrm{ml}$. of ethanol. By using Whatman No. 1 filter 
paper the extract was filtered after three days. After filtration, the extract was kept in air tight flask at $4^{\circ} \mathrm{C}$ for further studies.

\section{Flavonoids}

0.5 gram of plant powder was added to 5 $\mathrm{ml}$. of dilute ammonia solution and then concentrated $\mathrm{H}_{2} \mathrm{SO}_{4}$ was added. The signal of yellow color showed the presence of flavonoid which vanished later on standing [15].

\section{Steroids}

$1 \mathrm{ml}$. plant extract was added to $10 \mathrm{ml}$. of chloroform followed by the addition of concentrated $\mathrm{H}_{2} \mathrm{SO}_{4}$ on the side of the test tube. The arrival of red color in the upper portion and yellow with green florescence in Sulphuric acid $\left(\mathrm{H}_{2} \mathrm{SO}_{4}\right)$ layer indicated the occurrence of steroids [16].

\section{Tannins}

0.5 gram of plant powder was shaken with $100 \mathrm{ml}$. of distilled water and filtered. Then $0.1 \%$ ferric chloride reagent was added to $20 \mathrm{ml}$.of filtrate. The creation of blue green coloration specified the presence of tannins [17].

\section{Saponin}

0.5 gram of each plant powder was stirred with $5 \mathrm{ml}$. of distilled water. The realization of foaming bubbles on warming indicated the presence of saponin [18].

\section{Terpenoids}

0.5 gram of plant sample was shaken with $2 \mathrm{ml}$. of chloroform followed by the careful addition of concentrated $\mathrm{H}_{2} \mathrm{SO}_{4}$ to form a coating. A reddish-brown coloration was taken as preliminary evidence for the presence of terpenoids [19].

\section{Phlobatannins}

0.2 gram of each plant powder was bubbled in $1 \%$ aqueous $\mathrm{HCl}$, the appearance of red precipitate complete the presence of phlobatannins $[19,15]$.

\section{Anthraquinones}

$5 \mathrm{ml}$. of chloroform was stirred with 0.5 gram of extract, filtered and added 10\% ammonia solution to the filtrate. After shaking thoroughly the appearance of yellow or red color in the ammonical phase stated the presence of anthraquinones [19].

Minerals assessment

Energy Dispersive X-ray (EDX)

Spectrometer (Model Perkin Elmer 700) was used to determine the macro and micro minerals in the Centralized Resource Laboratory, University of Peshawar, Peshawar.

Results and Discussion

\section{Ethnobotanical and ethnomedicinal profile}

The current research work was carried out to investigate the biological spectra (leaf size, leaf shape, life form and phenology), ethnobotanical applications, phytochemical assessment and elemental profile of five species of Myrtaceae. Biological spectrum of leaf size classes were dominated by Mesophyll (40\%) followed by Microphyll, Nanophyll and Macrophyll each 20\% with simple leaf shape (Fig. 3). Life form spectra represented that Mesophanerophyte and Megaphanerophyte were the major classes each with (40\%) and Nanophanerophyte (20\%) (Table 1; Fig. 4). Phenological behavior showed that during collection time most plants were in pre reproductive stage $(60 \%)$, while $(40 \%)$ plants were at reproductive stage (Table 2; Fig. 5). Ethnobotanical $(80 \%)$ species were used in medicines, $(60 \%)$ as fuel followed by $40 \%$ each fruit, timber and ornamental (Table 3). Ethnomedicinal profile showed that the plants contained secondary metabolites tannins and oleanolic acid which is used as anti-malarial, anti-diabetic and antimicrobial (Table 4). Ethnomedicinal importance of the plants was also reported by [20-22].

\section{Elemental profile}

The plant species were quantitively investigated for 13 vital elements (Table 5; Fig. 6). A total of eight elements were found in all species among which six were macro elements $(\mathrm{C}, \mathrm{O}, \mathrm{Mg}, \mathrm{K}, \mathrm{S}$ and $\mathrm{Ca})$ and two were minor ( $\mathrm{Al}$ and $\mathrm{Si}$ ). The maximum Carbon content was observed in Callistemon lanceolatus (67.18\%) and 
minimum was found in Eucalyptus camaldulensis $(60.58 \%)$. In macro elements Nitrogen and Phosphorous were absent in Myrtus communis. The maximum amount of Iron was found in Eucalyptus camaldulensis $\quad(0.43 \%)$ followed by Myrtus communis (0.27\%) and Psidium guajava (0.20\%). Chlorine was present in Callistemon lanceolatus and Syzygium cumini while $\mathrm{Na}$ was only present in Callistemon lanceolatus. The macro and micronutrients are essential for the proper functioning of body and different enzymatic activities [23, 24]. The results agreed with $[25,26]$ which reported the same elements from Syzygium cumini and Psidium guajava.

\section{Phytochemical assessment}

The qualitative phytochemical screening of methanolic extracts showed the presence of terpenoid, flavonoids, steroids, tannins, saponins, phlobatannins and anthraquinones (Table 6). Flavonoids, saponins and anthraquinones were present in all species while phlobatannins were present only in Callistemon lanceolatus and Eucalyptus camaldulensis. The leaves extract of Syzygium cumini revealed the presence of saponins, flavonoids and tannins, which are used to treat constipation, diabetes and to stop blood discharge in the feces [8]. Flavonoids, saponins and anthraquinones were present in all plants extract which are used as anticancer, antimalarial, anti-inflammatory and antioxidant [27]. The present study also supported the findings of $[28,22]$ which also reported the similar phytochemical in leaves of these plants.

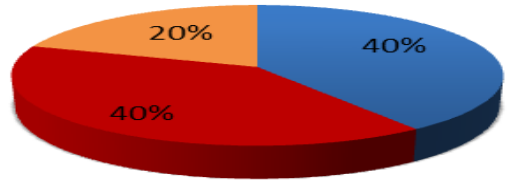

- Megaphanerophytes

Figure 3. Life form classes

Table 1. Summary of Biological spectra of Myrtaceae Plant species in Peshawar, Pakistan

A. Life form

\begin{tabular}{|c|c|c|c|}
\hline S. No. & Life form classes & No. of species & Percentage (\%) \\
\hline i. & Mesophanerophytes & 2 & 40 \\
\hline ii. & Megaphanerophytes & 2 & 40 \\
\hline iii. & Nanophanerophyte & 1 & 20 \\
\hline \multicolumn{2}{|c|}{ Total } & $\mathbf{5}$ & $\mathbf{1 0 0}$ \\
\hline
\end{tabular}

B. Leaf sizes

\begin{tabular}{|c|c|c|c|}
\hline S. No. & Leaf sizes classes & No. of species & Percentage $(\%)$ \\
\hline i. & Mesophyll & 2 & 40 \\
\hline ii. & Microphyll & 1 & 20 \\
\hline iii. & Nanophyll & 1 & 20 \\
\hline iv. & Macrophyll & 1 & 20 \\
\hline & Total & 5 & 100 \\
\hline
\end{tabular}

C. Leaf shape

\begin{tabular}{|c|c|c|c|}
\hline S. No. & Leaf shape classes & No. of species & Percentage (\%) \\
\hline i. & Simple & 5 & 100 \\
\hline
\end{tabular}




\begin{tabular}{|c|c|c|c|}
\hline \multicolumn{2}{|c|}{ Total } & 5 & 100 \\
\hline \multicolumn{4}{|c|}{ D. Phenology } \\
\hline S. No. & Phenological stages & No. of species & Percentage $(\%)$ \\
\hline i. & Pre reproductive (S1) & 3 & 60 \\
\hline ii. & Reproductive $\quad(\mathrm{S} 2)$ & 2 & 40 \\
\hline \multicolumn{2}{|r|}{ Total } & 5 & 100 \\
\hline
\end{tabular}

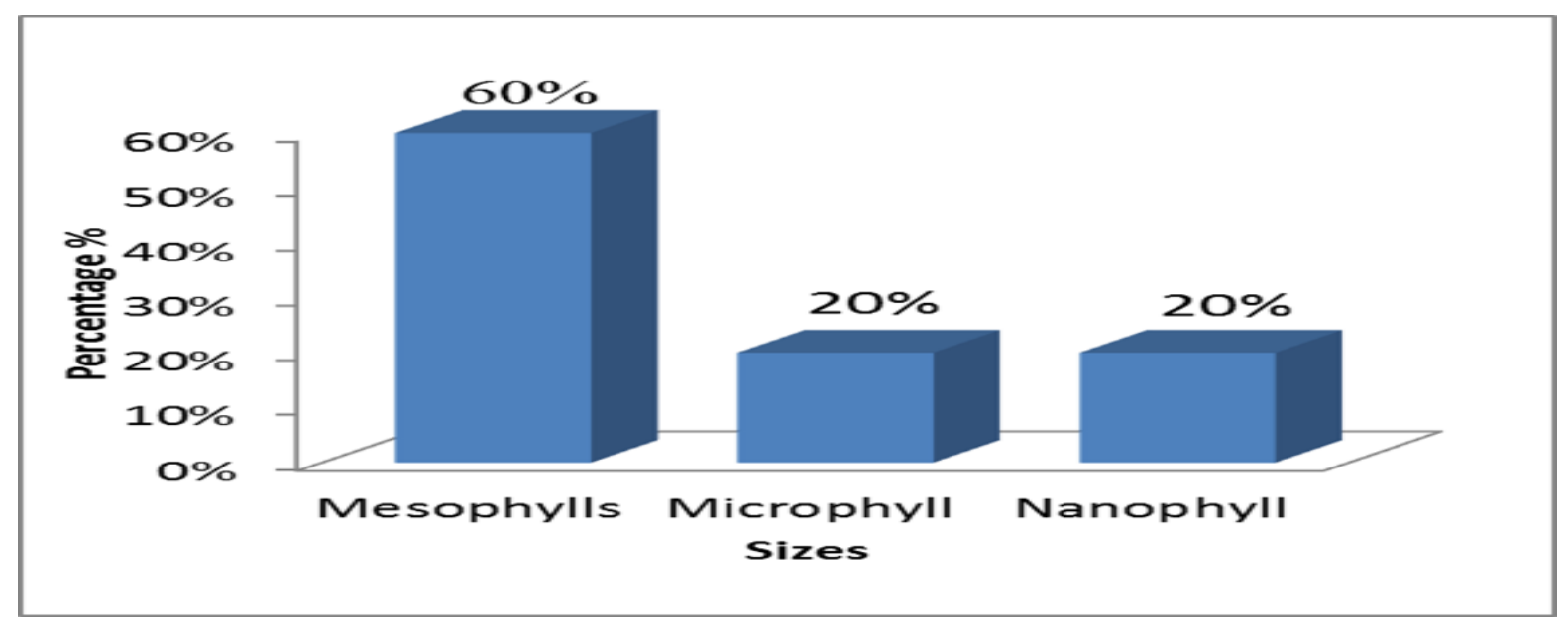

Figure 4. Leaf size classes

Table 2. Biological spectra of Myrtaceae Plant Species in Peshawar, Pakistan

\begin{tabular}{|c|c|c|c|c|c|}
\hline S. No. & Plant Species & Life form & Leaf size & Leaf shape & Phenology \\
\hline A. & \multicolumn{5}{|c|}{ Angiosperms } \\
\hline a. & \multicolumn{5}{|c|}{ Dicots } \\
\hline 1. & \multicolumn{5}{|c|}{ Family Myrtaceae } \\
\hline 1. & $\begin{array}{c}\text { Callistemon lanceolatus } \\
\text { (Sm.) Sweet. }\end{array}$ & MesP & Mic & S & S2 \\
\hline 2. & $\begin{array}{c}\text { Eucalyptus camaldulensis } \\
\text { Dehnh. }\end{array}$ & MegP & Mes & S & S1 \\
\hline 3. & Myrtus communis L. & NP & N & S & S1 \\
\hline 4. & Psidium guajava L. & MesP & Mac & S & S1 \\
\hline 5. & $\begin{array}{c}\text { Syzygium cumini }(\text { L.) } \\
\text { Skeels. }\end{array}$ & MegP & Mes & S & S2 \\
\hline
\end{tabular}

Keys: Mes P. Mesophanerophyte Np. Nanophanerophytes MegP. Megaphanerophytes Mic. Microphyll Mac. Macrophyll N. Nanophyll Mes. Mesophyll S. Simple S1. Pre-reproductive S2. Reproductive

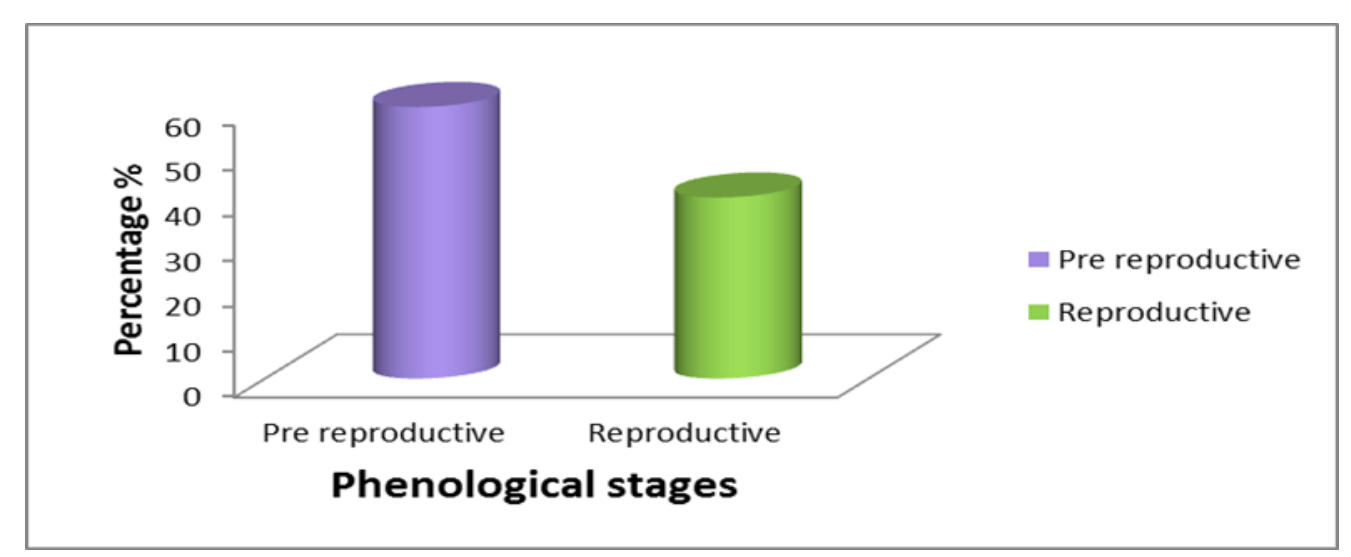

Figure 5. Phenological stages 
Table 3. Ethnobotanical profile of Myrtaceae Plant Speciesin Peshawar, Pakistan

\begin{tabular}{|c|c|c|c|c|c|c|}
\hline S. No. & Plant Species & $\mathbf{1 .}$ & $\mathbf{2 .}$ & $\mathbf{3 .}$ & $\mathbf{4 .}$ & $\mathbf{5 .}$ \\
\hline 1. & Callistemon lanceolatus (Sm.) Sweet & - & - & + & - & + \\
\hline 2. & Eucalyptus camaldulensis Dehnh. & - & + & + & - & - \\
\hline 3. & Myrtus communis L. & + & + & - & + & - \\
\hline 4. & Psidium guajava L. & + & + & - & + & - \\
\hline 5. & Syzygium cumini (L.) Skeels. & - & + & - & + & + \\
\hline & Total & $\mathbf{2}$ & $\mathbf{4}$ & $\mathbf{2}$ & $\mathbf{3}$ & $\mathbf{2}$ \\
\hline & $\mathbf{\%}$ & $\mathbf{4 0}$ & $\mathbf{8 0}$ & $\mathbf{4 0}$ & $\mathbf{6 0}$ & $\mathbf{4 0}$ \\
\hline
\end{tabular}

Keys: 1. Fruit 2. Fuel 3. Medicinal 4. Ornamental 5. Timber

Table 4. Ethnomedicinal uses of Myrtaceae Plant Species in Peshawar, Pakistan

\begin{tabular}{|c|c|c|c|c|c|c|c|}
\hline \multirow{2}{*}{ S. No. } & \multirow{2}{*}{ Plant Species } & \multicolumn{4}{|c|}{ Part used } & \multirow{2}{*}{ 苞 } & \multirow{2}{*}{ 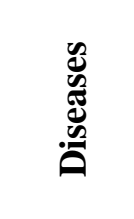 } \\
\hline & & Root & Stem & Leave & Flower & & \\
\hline 1. & $\begin{array}{c}\text { Callistemon lanceolatus (Sm.) } \\
\text { Sweet. }\end{array}$ & - & + & + & + & 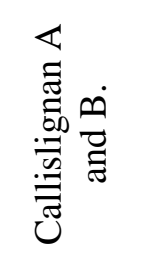 & 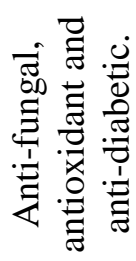 \\
\hline 2. & $\begin{array}{c}\text { Eucalyptus camaldulensis } \\
\text { Dehnh. }\end{array}$ & - & + & + & - & 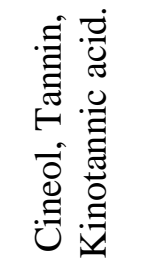 & 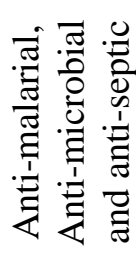 \\
\hline 3. & Myrtus communis L. & - & - & + & - & 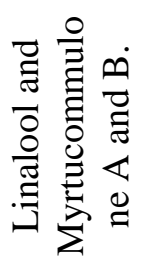 & 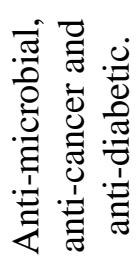 \\
\hline 4. & Psidium guajava L. & + & + & + & - & 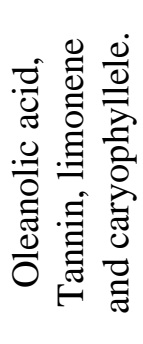 & 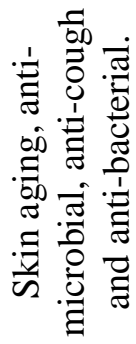 \\
\hline
\end{tabular}


Shah et al.

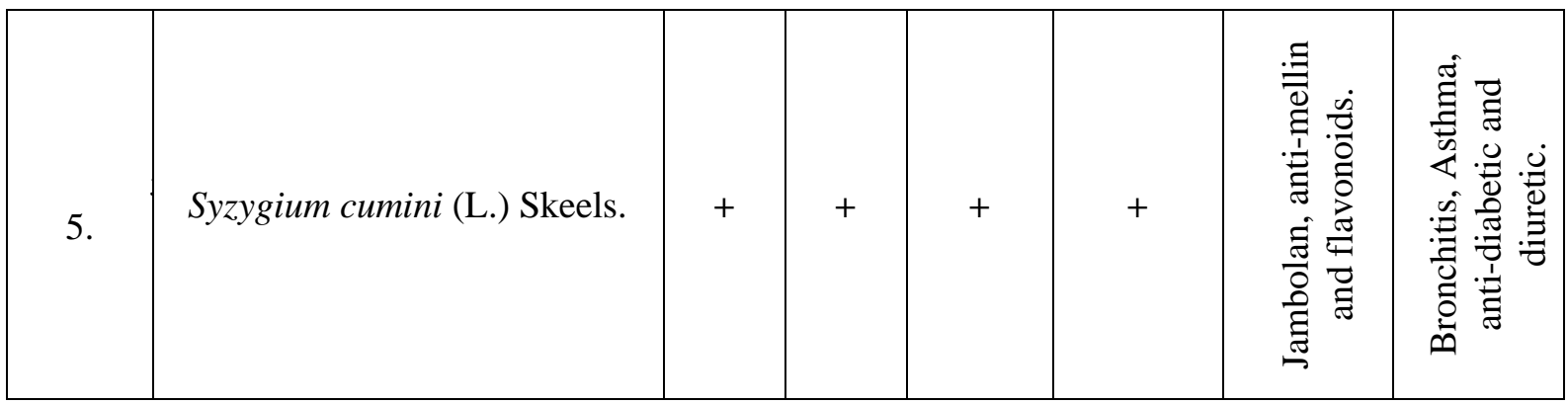

Table 5. Mineral contents in Myrtaceae Plant Species of Peshawar, Pakistan

\begin{tabular}{|c|c|c|c|c|c|c|c|c|c|c|c|c|c|c|}
\hline \multirow{3}{*}{$\begin{array}{l}\text { S. } \\
\text { No. }\end{array}$} & \multirow{3}{*}{$\begin{array}{c}\text { Plant } \\
\text { Species }\end{array}$} & \multicolumn{13}{|c|}{ Minerals \% } \\
\hline & & \multicolumn{8}{|c|}{ Major Elements } & \multicolumn{5}{|c|}{ Minor Elements } \\
\hline & & C & $\mathbf{N}$ & $\mathbf{O}$ & Mg & $\mathbf{K}$ & $\mathbf{P}$ & $\mathbf{S}$ & $\mathbf{C a}$ & Al & $\mathbf{S i}$ & $\mathrm{Fe}$ & Cl & $\mathbf{N a}$ \\
\hline 1. & $\begin{array}{l}\text { Callistemon } \\
\text { lanceolatus } \\
\text { (Sm.) Sweet }\end{array}$ & 67.18 & 7.78 & 34.10 & 0.17 & 0.75 & - & 0.19 & 1.00 & 0.19 & 0.39 & - & 0.38 & 0.15 \\
\hline 2. & $\begin{array}{c}\text { Eucalyptus } \\
\text { camaldulens } \\
\text { is Dehnh. }\end{array}$ & 60.58 & 5.12 & 36.90 & 0.28 & 1.24 & 0.34 & 0.14 & 2.47 & 0.18 & 0.31 & 0.43 & - & - \\
\hline 3. & $\begin{array}{c}\text { Myrtus } \\
\text { communis L. }\end{array}$ & 65.50 & - & 34.26 & 0.27 & 0.80 & - & 0.15 & 1.02 & 0.20 & 0.31 & 0.27 & - & - \\
\hline 4. & $\begin{array}{c}\text { Psidium } \\
\text { guajava L. }\end{array}$ & 61.99 & 6.85 & 36.04 & 0.35 & 1.24 & 0.18 & 0.32 & 1.99 & 0.23 & 0.65 & 0.20 & - & - \\
\hline 5. & $\begin{array}{l}\text { Syzygium } \\
\text { cumini (L.) } \\
\text { Skeels. }\end{array}$ & 60.62 & 6.99 & 36.66 & 0.69 & 0.99 & 0.19 & 0.23 & 1.72 & 0.12 & 0.41 & - & 0.31 & - \\
\hline
\end{tabular}

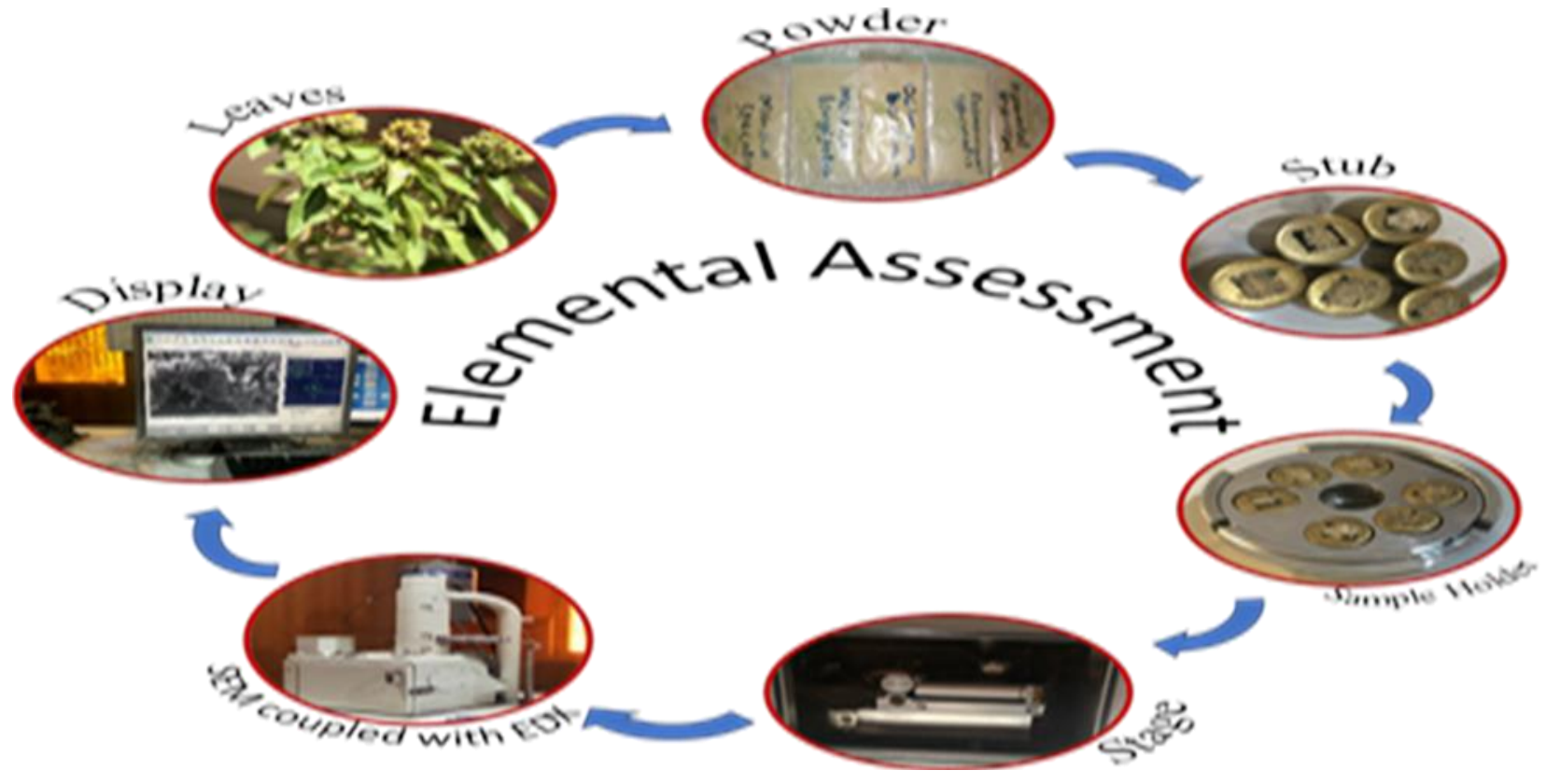

Figure 6. Different steps of elemental analysis 
Table 6. Phytochemical screening of Myrtaceae plant Species in Peshawar, Pakistan

\begin{tabular}{|c|c|c|c|c|c|c|c|c|}
\hline $\begin{array}{l}\text { S. } \\
\text { No. }\end{array}$ & Plants species & 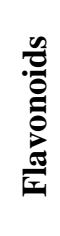 & & 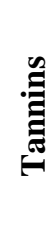 & 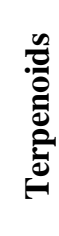 & 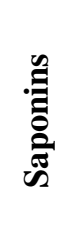 & 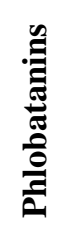 & 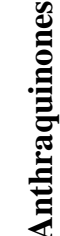 \\
\hline 1. & $\begin{array}{c}\text { Callistemon lanceolatus } \\
(\mathrm{Sm} .) \text { Sweet }\end{array}$ & + & + & + & + & + & + & + \\
\hline 2. & $\begin{array}{c}\text { Eucalyptus camaldulensis } \\
\text { Dehnh. }\end{array}$ & + & + & + & + & + & + & + \\
\hline 3. & Myrtus communis L. & + & - & - & + & + & - & + \\
\hline 4. & Psidium guajava $\mathrm{L}$. & + & - & - & - & + & - & + \\
\hline 5. & $\begin{array}{l}\text { Syzygium cumini (L.) } \\
\text { Skeels. }\end{array}$ & + & + & + & - & + & - & + \\
\hline
\end{tabular}

\section{Conclusion}

Phytochemical assessment and elemental analysis of five species of Myrtaceae was carried out for the first time for the species collected from Peshawar University campus. The current study concluded that five species of family Myrtaceae contains 13 different minor and major elements. From the above information's it is clear that phytochemicals of these species are of great importance and used for curing of different disease. And all the medicinal properties of these plants are due to above mentioned phytochemicals.

\section{Authors' contributions}

Conceived and designed the experiments: $\mathrm{L}$ Khattak \& G Rukh, Performed the experiments: S Khan \& S Shah, Analyzed the data: S Khan \& SM Shah, Contributed materials/ analysis/ tools: S Khan, L Khattak \& G Rukh, Wrote the paper: S Khan \& S Shah.

\section{Acknowledgment}

The authors are thankful to Department of Botany and Centralize resource laboratory, University of Peshawar for their help in performing Elemental and Phytochemical experiments.

\section{References}

1. Alam N, Shinwari ZK, Ilyas M \& Ullah Z (2011). Indigenous knowledge of medicinal plants of Chagharzai Valley,
District Buner, Pakistan. Pak J Bot 43: 773-780.

2. Ahmad KS, Kayani WK, Hameed M, Ahmad F \& Nawaz T (2012). Floristic diversity and ethnobotany of Senhsa, District Kotli, Azad Jammu \& Kashmir (Pakistan). Pak J Bot 44: 195-201.

3. Hameed M, Ashraf M, Al-Quriany F, Nawaz T, Ahmad MSA \& Younis A (2011). Medicinal flora of the Cholistan desert: a review. Pak J Bot 43: 39-50.

4. Ayyanar M \& Pandurangan SB (2012). Syzygium cumini (L.) Skeels: A review of its phytochemical constituents and traditional uses. Asian Pac J Trop Biomed 2(3): 240-246.

5. Asif M (2014). Bioactive phytochemical constituents of some edible fruits of Myrtaceae family. Ameri J Nut Res 1: 117.

6. Kaneria M \& Chanda S (2011). Phytochemical and pharmacognostic evalvation of leaves of Psidium guajava L. (Myrtaceae). Pharma J 3: 41-45.

7. Adeniyi BA \& Ayepola OO (2008). The phytochemical screening and antimicrobial activity of leaf extract of eucalyptus camaldulensis and eucalyptus torelliana (Myrtaceae) Res J Med Plants 2(1): 34-38.

8. Alam MR, Rahman AB, Moniruzzaman M, Kadir MF, Haque MA, Alvi MRH \& 
Ratan M (2012). Evaluation of antidiabetic phytochemicals in Syzygium cumini (L.) Skeels (Family: Myrtaceae). J Appl Pharma Sci 2(10): 094-098.

9. Spencer RD, Lumley PF \& Harden GJ (eds.) (1991). Flora of New South Wales. Callistemon Sydney: New South Wales University Press 2: 168-173.

10. Salem MZM, Ali HM, El-Shanhorey NA \& Megeed AA (2013). Evaluation of extracts and essential oil from Callistemon viminalis leaves: Antibacterial and antioxidant activities, total phenolic and flavonoid Contents. Asian Pac J Trop Medi 785-791.

11. Qader KO, Al-Saadi SAAM \& Al-Saadi TA (2017). Chemical Composition of Myrtus communis L. (Myrtaceae) Fruits. J Appl Life Sci Inter 12(3): 1-8.

12. Hussain F (1989). Field and Laboratory manual of Plant Ecology. UGC, Islamabad.

13. Hussain F, Shah SM, Badshah L \& Durrani MJ (2015). Diversity and ecological characteristics of flora of Mastuj valley, district Chitral, Hindukush range, Pakistan. Pak J Bot 47(2): 495510.

14. Raunkiaer CC (1934). The life form of plants and statistical plant geography. Oxford University press, London.

15. Sofowora A (1993). Recent trends in research into African medicinal plants. $J$ of Ethnopharac 38(2-3): 197-208.

16. Inas MK \& Aly AA (2017). Preliminary Phytochemical Screening of Different Solvent Extracts of Some Medicinal plants. Middle East J Appl Sci 7(2): 226231.

17. Trease GE \& Evans WC (1989). Pharmacognsy. 11th edn. Brailliar Tiridel Can. Macmillian publishers.

18. Obadoni BO \& Ochuko PO (2001). Phytochemical Studies and Comparative Efficacy of the Crude Extracts of Some Homeostatic Plants in Edo and Delta States of Nigeria. Global J Pure and Appl Sci 8: 203-208.
19. Harborne JB (1973). Phenolic compounds. Phytochemical methods, Springer 33-88.

20. Imelda LR \& Bandiola TMB (2017). Phytochemical Screening of Syzygium Cumini (Myrtaceae) Leaf Extracts Using Different Solvents of Extraction. Der Pharmacia Lettre 9 (2): 74-78.

21. Medhi SM, Reza SA, Mahnaz K, Reza AM, Abbas H, Fatemeh M \& Hassan V (2010). Phytochemistry and larvicidal activity of Eucalyptus camaldulensis against malaria vector, Anopheles stephensi. Asian Paci J Trop Medi 841845.

22. Thakur N \& Arya V (2014). Preliminary Phytochemical Analysis of the Extracts of Psidium Leaves. Middle East J Sci Res 19(11): 1421-14.

23. Hannah MAC \& Krishnakumari S (2015). Analysis of Mineral Elements, Proximate and Nutritive value in Citrullus vulgaris Schrad. (Watermelon) seed extracts. The Pharma Innov J 4(8): 07-11.

24. Khan MN, Ali S, Akram H, Jan F, Haq IU, Shah SM, Adnan M, Hanif SM \& Siddique AN (2019). Elemental analysis of five selected grasses of sub family Pooideae from University of Peshawar Campus, KP, Pakistan. Pure and Appl Biol 8(2): 1296-1306.

25. Rai PK, Rai NK, Rai AK \& Watal G (2007). Role of LIBS in Elemental Analysis of Psidium guajava Responsible for Glycemic Potential. Instrum Sci and Tech 35(5): 507-522.

26. Pradhan M (2016). Phytochemistry, Pharmacology and Novel Delivery Applications of Syzygium cumini (L.). Inter J Phar and Pharmac Res 7(1): 659675.

27. Panche AN, Diwan AD \& Chandra SR (2016). Review article Flavonoids: an overview, J Nutr Sci 5 (47): 1-15.

28. Shayoub MEH, Dawoud ADH, Abdelmageed MAM, Ehassan AM \& Ehassan AM (2015). Phytochemical analysis of leaves extract of Eucalyptus camaldulensis Dehnh. Omdurman J Pharmac Sci 2(1): 64. 